Nevşehir Bilim ve Teknoloji Dergisi Cilt 6(2) 605-618 2017

DOI: 10.17100/nevbiltek.292995

URL: http://dx.doi.org/10.17100/nevbiltek.292995

\title{
Kısa Ömürlü Ürünlerin Tedarik Zincirinin Modellenmesi ve Simülasyon
}

\section{Çalışması}

\author{
İbrahim DOĞAN ${ }^{1, *}$, Ahmet TEKKEŞIN ${ }^{2}$, Ahmet KARA ${ }^{1}$ \\ ${ }^{1}$ Erciyes Üniversitesi, Mühendislik Fakültesi, Endüstri Mühendisliği Bölümü, Kayseri \\ ${ }^{2}$ İkinci Hava İkmal Bakım Merkezi Komutanlı̆̆g Plan Program Başkanlığl, Kayseri \\ $\ddot{\mathbf{O z}}$
}

Bu çalışmada kısa ömürlü ürünlerin stok yönetimi seri bir tedarik zinciri üzerinde incelenmiştir. Müşteri, perakendeci ve üreticiden oluşan üç aşamalı tedarik yapısının stok seviyesi ve sipariş verme noktaları simülasyon yardımıyla modellenmiş ve en uygun parametreler simülasyon optimizasyonu yaklaşımı ile tespit edilmiştir. Stok yönetimi simülasyon çalışmalarında merkezi ve merkezi olmayan stok yönetimi incelenmiş, çıkan sonuçlar karşılaştırmalı tablolarla gösterilmiştir. Çalışmada toplam tedarik zinciri maliyetinin minimize edilmesi ve müşteri memnuniyet seviyesinin arttırılması performans ölçütleri olarak göz önüne alınmıştır.

Anahtar Kelimeler: Kısa ömürlü ürünlerde stok yönetimi, Tedarik zinciri yönetimi, Stok yönetimi, Simülasyon

\section{Supply Chain Modelling of Perishable Products and Simulation Study}

Abstract

In this study, inventory management of perishable products is studied in multi-stage supply chain setting. In a three stage supply chain setting which consists of customer, retailer and manufacturer, perishable inventory management is modeled and parameters of the model are determined with simulation optimization approach. A simulation program is used for modeling inventory management, centralized and decentralized inventory management is examined, and the results are presented on comparative tables. In study, minimization of total cost of supply chain and improving customer satisfaction level are considered as performance measures.

Keywords: Stock management of perishable products, Supply chain management, Stock Management, Simulation.

\footnotetext{
*e-mail: idogan@erciyes.edu.tr
} 
Doğan İ., Tekkeşin A., Kara A.

\section{Giriş}

Kısa ömürlü ürünlerin bozulup atılması, emek ve kaynakların israf olmasına sebep olmaktadır. Her y1l yaklaşık 1,3 milyar ton yiyeceğin israf edildiği tahmin edilmektedir [1]. Gereğinden fazla sebze veya meyve stoklayan bir marketteki ürünlerin bozulması zincirleme olarak dağıtıcının fazladan yakıt kullanmasına, üreticinin fazladan su, enerji ve en önemlisi emeğinin boşa harcanmasına neden olmaktadır. Su, petrol, gaz, gibi doğal kaynakların hızla tükendiği günümüzde israfın önlenebilmesi, gerçek ihtiyaca göre üretim yapmaktan geçmektedir.

Tedarik zincirinde, firmaların maliyetlerini etkileyen ve kârlılı̆̆ını artıracak en önemli unsurlardan biri etkin stok yönetimine sahip olmaktır. Geleneksel tedarik zinciri stok yönetiminde, genellikle altı aydan daha fazla uzun ömürlü ürünler incelenmiştir. Diğer taraftan çok aşamalı tedarik zinciri yapısı içerisinde kısa ömürlü ürünlerin stok politikalarını inceleyen çalışma sayısı da sınırlıdır. Endüstrideki yaygın kullanımda kısa ömürlü ürünler üreten firmaların stok yönetiminde, uzun ömürlü ürünler için uygulanan stok politikalarını devam ettirmeleri bir takım verimsizliklere sebep olmaktadır [2]. Bu durum firmaların bozulan ürün maliyeti ile yok satma maliyetini artırmakta ve müşteri memnuniyetsizliğine sebep olmaktadır.

Bu çalışmada kısa ömürlü ürünlerin stok yönetimi müşteri, perakendeci ve üreticiden oluşan bir tedarik zinciri üzerinde incelenmiştir. Kısa ömürlü ürünlerin stok yönetimi geleneksel dayanıklı ürünlerden farklı özellikler göstermektedir. Dayanıklı ürünlerin stok yönetiminde temel anlamda ürünün yaşı göz önüne alınmamakta, sadece uygulamada ürünlerin zaman içerisinde değer yitireceği göz önüne alınarak pek çok uygulamada ilk giren ilk çıkar (First In First Out - FIFO) çekme prensibi uygulanmaktadır. Perakendecilerin raflarında aynı kaygılardan dolayı son kullanıcıların daha rahat erişebileceği yerlerde daha eski tarihli ürünleri ve arkalarında da yeni tarihli ürünleri yerleştirdiklerini görmek mümkündür.

$\mathrm{Bu}$ çalışmamızda sadece tek bir firmanın stok yönetimi ile değil tüm tedarik zincirinde kısa ömürlü ürünlerin stok yönetimi ile ilgilenilmiştir. Günümüzde artık şirketlerin değil tedarik zincirlerinin rekabet halinde olduğu bilinmektedir [3]. Tedarik zinciri yönetimi en temel anlamda müşteriler, perakendeciler, dağıtıcılar, toptancılar, üreticiler, tedarikçiler gibi birçok aşamadan oluşan, bu aşamalar arasında malzeme, para ve bilgi akışının yönetilmesi olarak tanımlayabiliriz. Çok aşamalı tedarik zincirinde uzun ömürlü ürünlerin stok yönetimi alanında çok fazla çalışma bulunmasına karşılık kısa ömürlü ürünler ile ilgili çalışmalar daha kısıtlıdır. Bu çalışmada ayrıca farklı bilgi paylaşımlarının kısa ömürlü ürünlerin stok yönetimi üzerine etkisi de incelenmiştir.

Kısa ömürlü ürünlerin stok yönetiminde geleneksel ürünlerdeki gibi sadece miktarı göz önüne alarak stok yenilemenin yapılması bir takım verimsizliklere sebep olmaktadır [2]. Kısa ömürlü ürünlerde miktarın yanında ürünün yaşının başka deyişle kalan ömrünün de göz önüne alınması gerekmektedir. Stoklarda farklı yaşlarda ürünlerin bulunacak olması problemin hem modelleme hem de çözümleme zorluğunu artırmaktadır. Literatürde bu zorluğu çözmek için farklı yaklaşık çözümler önerilmektedir. Bu çalışmada literatürdeki pek çok çalışmadan farklı olarak sadece perakendecinin olduğu tek aşama değerlendirilmemiş, üretici ve perakendecinin bulunduğu çok aşamalı tedarik zinciri benzetim ile modellenerek stok politikası geliştirilmiş ve uygulanmıştır. Stok politikası geliştirilirken sadece etkinliği değil aynı zamanda uygulanabilirliği de göz önüne alınmıştır. Artan rekabet koşulları ve hızlı tüketim 
neticesinde TZY'nin önemli konularından birisi olan kısa ömürlü ürünler için etkin ve uygulanabilirliği pratik bir stok politikası geliştirilmesi hedeflenmiştir. Ayrıca, stokastik müşteri talebi, ürünlerin yapısının bozulabilir olması ve ürünlerin tedarik zinciri boyunca yaşını izlemek gibi bir takım zorluklar vardır [26].

Ürünlerin toplam yaşları sürekli kontrol edilerek kısa ömürlü ürünlerin, elde gereğinden fazla bulundurulmasının ve bozulmasının önüne geçilmesi amaçlanmıştır. Sipariş maliyeti, yok satma maliyeti, elde bulundurma maliyeti ve bozulan ürün maliyetinden oluşan toplam tedarik zinciri maliyetinin minimize edilmesi hedeflenmektedir. Simülasyon programı kullanılarak farklı senaryolar karşılaştırılarak stok yönetiminde kritik parametreler tespit edilmiş, ayrıca merkezi ve merkezi olmayan stok yönetimi incelenmiş, çıkan sonuçlar karşılaş̧ırmalı tablolarla gösterilmiştir. Tedarik zincirinde tek bir oyuncunun stok yönetiminden farklı olarak müşteri, perakendeci ve üreticiden oluşan çok aşamalı kısa ömürlü ürünlerin stok yönetimi modellenerek literatüre yeni bir çalışma kazanılması hedeflenmiştir.

Çalışmanın bundan sonraki kısımları şu şekilde düzenlenmiştir. İkinci bölümde kısa ömürlü ürünlerin stok yönetimi ve stok yönetiminde bilgi paylaşımı konularında literatürdeki çalışmaları, üçüncü bölümde simülasyon modeli ve akış diyagramları gösterilmiştir. Dördüncü bölümde modelin simülasyon çalışmasından elde edilen bulgular incelenmiş ve analiz edilmiştir. Son olarak da çalışma kazanımları anlatılmış ve değerlendirmelerde bulunularak çalışma tamamlanmıştır.

\section{Literatür}

Günlük yaşantımızda raf ömrü olan ekmek, süt gibi çeşitli gıdaları; kan, ilaç vb. sağlık ürünlerini; endüstride kullanılan lastik esaslı conta vb. ürünleri kullanmaktayız. Çalışmanın konusu TZY'de kısa ömürlü ürünler ile ilgili literatürde üretim, pazarlama, dağıtım, stok, finans, maliyet, vb. konularda çok fazla çalışma bulmak mümkündür [4 - 7]. Sabit raf ömürlü ve rassal talepli bozulabilir ürünler üzerine literatürde yapılan ilk çalışma Van Zyl'nın 1964'de yayınladığı çalışmadır [8]. Bu çalışmayı daha sonra Nahmias'ın 1975'deki çalışması ve Fries'in 1975'deki yayını devam etmiştir [9], [10]. Bozulabilir ürünlerin envanter yönetimi üzerine kapsamlı literatür taraması da yapılmıştır [11-14]. Nahmias'a göre bozulabilir ürünlerin raf ömrü iki kategoriye ayrılabilir. Bunlardan ilki sabit raf ömrü olan ürünler ve ikincisi ise rassal raf ömrü olan ürünlerdir. Bakker vd. (2012) kısa ömürlü ürünler ile ilgili 2001-2011 yılları arası uluslararası 200'den fazla büyük dergide yayınlanan 227 makaleyi inceleyerek literatürde yer alan çalışmaları büyük oranda incelemiştir.

Kısa ömürlü ürünlerin ekonomik sipariş verme noktasını (EOQ) belirlemeye yönelik Padmanabhan ve Vrat (1993) tarafından üç farklı matematiksel model geliştirmişlerdir. Birinci modelde karşılanamayan siparişe izin verilmemiş, ikinci modelde bütün olarak karşılanmayan siparişe izin verilmiş ve son modelde parçalı olarak siparişlerin karşılanmaları dikkate alınmıştır [15]. Kalpakam ve Shanthi (1998) ise kısa ömürlü ürünlerin stok politikası ile ilgili kurdukları matematiksel modelde talebi Poisson, ürünlerin ömürlerini Üstel dağılıma uygun, ürünlerin bozulma sürelerini sabit olarak varsayarak uzun dönem maliyet oranını minimize etmek için optimum parametreler elde edilmeye çalışılmıştır [16]. Bu konuda diğer bir çalışmada müşterilerin daha taze ürünü tercih ettiklerini gözlemlenmiştir. Kurulan model; EWA politikası olan stok pozisyonun gün sonu gelmeden tahmini bozulan ürün miktarını da hesaplayarak sipariş vermeye yöneliktir [17]. Pierskalla ve Roach (1972) kurdukları matematiksel modelde toplam faydayı arttırmak, karşılanamayan siparişi minimize etmek ve ürünlerin son yaş 
kategorisine gelmesini minimize etmek olan üç farklı amaç fonksiyonu göz önüne alınmıştır [4]. PaulsWorm vd. (2016) durağan olmayan müşteri talebine sahip bozulabilir ürünler için envanter kontrol politikası önermişlerdir [31].

Kısa ömürlü ürünler alanında özellikle literatürde çalışan konulardan bir tanesi de kan ve kan ürünlerinin stok yönetimi ile ilgilidir. Çeşitli kan grupları olması ve talebin hangi kan grubundan olunacağı bilinememesi çok kısa ömürlü olan kanın stok yönetimini karmaşık hale getirmektedir. Bu alanda, Katsaliaki (2008) yaptığı çalışma ile kanın maliyetini etkin yönetmeyi amaçlamıştır. Çalışmasında İngiltere Ulusal Kan Bankasından (UKB) aldığı verileri kullanmış, UKB'nin kanı temin ettiği üç hastaneyi ve bu hastanelerin değişken taleplerini simüle etmiştir [5]. Rytilä ve Spens (2006) kan tedarik zincirinin etkin yönetilmesi için farklı senaryoların simülasyonlarını gerçekleştirerek her bir grup kanın bozulmalarını ve yok satma maliyetini minimize etmeyi amaçlamışlardır [6]. Ghandforoush ve Sen (2010) de çalışmasında mobil kan merkezlerinde trombositlerin üretimi ve bölgesel kan merkezine trombositlerin ulaştırılması için karar destek sistemi sunmaktadırlar. Karar destek sistemi içerisinde doğrusal olmayan model, 0-1 tam sayılı doğrusal modelle dönüştürülmüş; talep ve tedarik çok hızlı karşılaştırılarak fazla ürünün gereksiz stoklaması ve maliyetin minimize edilmesi hedeflenmiştir [18]. Önal vd. (2015) bozulabilir ürünlerde ekonomik parti büyüklüğünü ortaya koymak için bir matematiksel formülasyon sunmuşlardır [30].

Tedarik zincirinde kısa ömürlü ürünlerin daha etkin yönetilmesinin bilgi paylaşımı ile mümkün olduğunu gösteren çalışmalarda bulunmaktadır [19-22]. Sarathi vd. (2014) oluşturdukları matematiksel modelde kısa ömürlü ürünlerin üretici ve perakendeci olmak üzere iki aşamalı tedarik zincirinde fiyat ve stok miktarı üzerinde etkisini incelemişlerdir. Aşamada yer alan birimler arasında bilgi paylaşımı ile koordineli çalışarak tedarik zincirinde önemli kar artış1 olduğu gösterilmiştir [23]. Kısa ömürlü ürünlerin bilgi paylaşımı ile Kärkkäinen (2003) tarafından yapılan diğer çalışmada; kısa ömürlü ürünlerin, tedarik zincirinin performansını kapasite planlamada ve stok yönetiminde olumsuz etkilediğini incelemiştir [7]. Merkuryev vd. (2002) ise yaptığı çalışmada, merkezi ve merkezi olmayan stok yönetiminde; perakendeci, toptancı, dağıtıcı ve üreticiden oluşan dört aşamalı tedarik zincirinde stok dalgalanması ölçülmüştür. Bilgi paylaşımı sonucu merkezi stok yönetiminin siparişteki standart sapma, stok miktarı ve servis hizmeti alanlarında merkezi olmayan stok yönetimine göre çok daha faydalı olduğu gözlemlenmiştir [24]. Chatfield vd. (2004) yaptıkları çalışmada değişkenliğin, daha fazla yatırım, üretim ve maliyet artışına sebep olduğunu gözlemlemiş ve bilgi paylaşımının tedarik zincirinde etkisini "SISCO" simülasyon programında incelemiştir [19]. Disney ve Towill (2003) satıcı tarafından yönetilen tedarik zinciri ile klasik tedarik zincirinin performans karşılaşırmasını ortaya koymuşlardır. Klasik tedarik yapısında her aşama kendi tedarik seviyesinden sorumlu olduğunu, ancak satıcı tarafindan yönetilen tedarik zincirinde, satıcı müşterinin stok yönetim sorumluluğunu almakta olduğunu göstermiştir [20].

Vieira (2004) kurduğu tedarik zinciri modelinde bir market, üç perakendeci, bir üretici ve üç tedarikçiden oluşan dört aşamalı yapıyı simülasyon modeli ile modellemiş ve farklı bilgi paylaşımı düzeylerinde ortalama stok miktarı ve servis düzeyini ölçmüşlerdir [25]. Luo vd. (2017) kapasitesi sınırlı olan iki tedarikçi ve sınırlı kapasiteye sahip bir perakendeciden oluşan stokastik talebe sahip iki kademeli tedarik zinciri için envanter kontrol yönetimi problemini ele almışlardır [27]. Kaasgari vd. (2017) sistem çapında ortalama toplam maliyeti en aza indirgemek için merkezi ortamında bozulabilir ürünlerinin 
stoklarının nasıl kontrol edilebileceğini belirlemişlerdir [28]. Bozulabilir ürüne sahip bir tedarikçi ve birden fazla perakende satıcısı sistemi için merkezi stratejisi altındaki üretim-envanter modeli Taleizadeh vd. (2015) tarafından incelenmiştir. Optimuma yakın değerleri belirlemek için kâr fonksiyonun konkav olduğunu kanıtlamışlardır. Bu çalışmada, tedarik zinciri yapısı içerisinde klasik stok yönetiminde sipariş noktalarını belirlemek için miktar kontrolünün yanında, stokta bulunun ürünlerin kalan yaşları dikkate alınmıştır. Ele alınan problemin amacı stoksuz kalma, yok satma ve bozulan ürün maliyetlerinin azaltılmasidır.

\section{Model}

Tedarik zincirinde kısa ömürlü ürünlerin stok yönetimi konusunda yapılan bu çalı̧mada kısa ömürlü ürünlerin stok yönetimi yeni bir stok politikası geliştirilerek modellenmiştir. İncelenen tedarik zinciri Şekil 1'de gösterildiği gibi müşteriler, perakendeci ve üreticiden oluşmaktadır. Üretici sınırsız kapasiteye sahip bir tedarikçiden siparişlerini karşılamaktadır. Tedarikçi ile üretici, üretici ile perakendeci arasında sabit bir temin süresi bulunmaktadır. Tedarikçi sınırsız kapasiteye sahip olduğundan verilen siparişler temin süresinde belirtilen gecikmeden sonra üreticinin stoklarına ulaşmaktadır. Perakendecinin, üreticinin stoklarından karşılanmayan siparişleri gecikmiş sevkiyata (backorder) sebep olmaktadır. Ürünler üreticinin stoklarına geldiği zaman öncelikle bu gecikmiş sevkiyatlar üretici tarafindan karşılanmaktadır. Perakendecinin üreticiye siparişleri aynı şekilde belirli bir temin süresi geçtikten sonra stoklarına girmektedir.

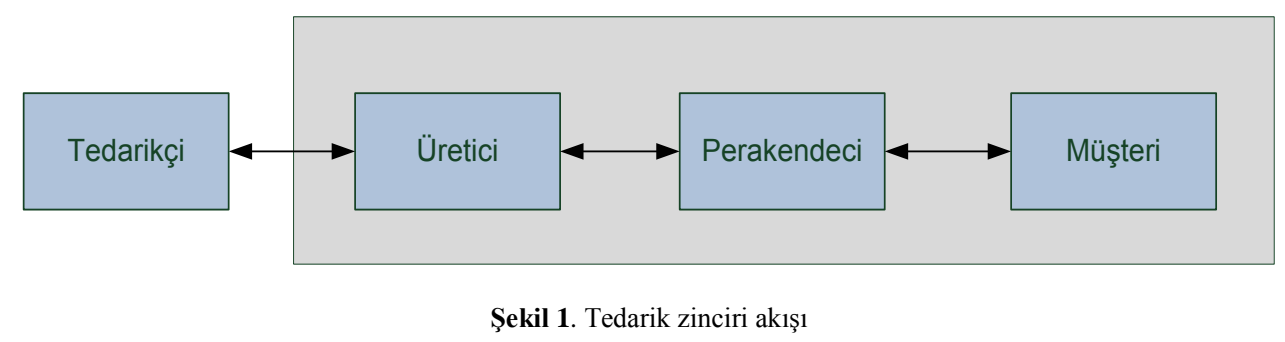

Müşterinin geliş süreleri rassal olarak kabul edilmiş, her müşterinin birer adet ürün talebinde bulunduğu kabul edilmiştir. Müşterinin talebi perakendecinin stoklarından karşılanmakta, eğer müşterinin talepleri stoklardan karşlanamaz ise stoksuz kalma başka deyişle kayıp satışla (lost sales) karşılaşılmaktadır. Ayrıca literatürdeki yapılan çalışmalardan farklı olarak bu çalışmada, kısa ömürlü ürünün yaşlanması tedarikçinin ürünü göndermesiyle başlamaktadır. Literatürdeki pek çok çalışmada ise yaşlanma, ürünün perakendecinin stoklarına girdikten sonra başladığı varsayılmaktadır.

Çalışmada müşteri gelişleri rassal ve her müşteri bir ürün talep ettiğinden dolayı, belirlenen dönem içerisinde müşteri talep miktarının da rassal olduğu kabul edilmektedir. Ürünün tedarik süresinin ise sabit olduğu varsayılmış, bu sayede ürünlerin yaşlanmaları düzenli şekilde kontrol edilmiştir. Ürünler sistemden ilk giren ilk çıkar (FIFO) çekme prensibine göre çekilerek daha yaşlı ürünler stoklardan çıkarılarak bozulma maliyeti azaltılmıştır.

Uzun ömürlü ürünlerin stok yönetiminden farklı olarak kısa ömürlü ürünlerin miktar ve yaş kontrolü yapılması gerektiğinden, kısa ömürlü ürünlerin stok yönetiminde sadece ürünleri sayısal olarak takip eden değil aynı zamanda ürünlerin yaşlarını başka bir deyişle kalan ömürlerini takip eden bir 
modele ihtiyaç bulunmaktadır. Örneğin $t$ gününde, ömürlerinin sonlarına gelmiş fakat sayısal olarak yeterli miktarda görülen ürünler, stok kontrolü sadece miktara göre gerçekleşirse herhangi bir siparişe gerek olmadığı çıkarımında bulunulacaktır. Fakat çok yakında stokların birçoğu kullanılmadan bozulacağından stoksuz kalmak kaçınılmaz olacaktır. Özellikle temin süresinin de bulunmasından dolayı tedarik zinciri performans bakımından etkinliğini kaybedecek ve birçok maliyete katlanmak zorunda kalınacaktır. Bu bozucu etki sadece zincirin sonundaki perakendeciyi değil satış yapamayan ve ürün akışı gerçekleşmeyen tüm zinciri etkileyecektir. Dolayısıyla burada geliştirdiğimiz stok politikasında sadece ürünün miktar olarak kontrolü değil aynı zamanda kalan ömürleri takip edilerek stokların güncellenmesi gerçekleştirilmektedir.

Bu çalışmada stok yönetiminde miktarı ve ürünlerin kalan ömürlerini göz önüne alan iki farklı kontrol gerçekleştirilmektedir. Birinci kontrolde stokta yeterli ürün olup/olmadığg kontrol edilerek stok düzeyine göre sipariş miktarının belirlemesinde $(s, S)$ politikası uygulanmış, ikinci kontrolde ise stoktaki ürünlerin kalan toplam yaşları hesaplanarak sipariş verilmiştir. Bu çalışmada göz önüne alınan performans ölçütü genel olarak tedarik zinciri içerisinde gerçekleşen toplam tedarik zinciri maliyetinin minimizasyonudur. Karar değişkenleri 10 gün 1sınma periyodunda beş y1l süresince çalıştırılarak öncelikle optimize edilmiş, çıkan optimum karar değişkenleri aynı sürede tekrardan simüle edilerek ortalama maliyet değerleri hesaplanmıştır. Modelde kullanılan karar değişkenleri ve parametreler Tablo 1 'de gösterilmiştir.

Tablo 1. Model Parametreleri ve karar değişkenleri

\begin{tabular}{lll}
\hline \multirow{3}{*}{$\begin{array}{l}\text { Karar } \\
\text { Değişkenleri }\end{array}$} & Üretici Üst Sipariş Noktası & Perakendeci Yaş Kontrolü Sonrası Sipariş Miktarı \\
& Perakendeci Üst Sipariş Noktası & Üretici Stoklarının Kalan Yaşı İçin Alt Sınır \\
& Perakendeci Alt Stok Seviyesi & Perakendeci Stoklarının Kalan Yaşı İçin Alt Sınır \\
\hline \multirow{4}{*}{ Parametreler } & Sistemde Geçen Gün & \\
& Ürünün Sistemdeki Yaşı & Üreticinin Elde Bulundurma Maliyeti \\
& Müşterinin Perakendeciden Talep Miktarı & Perakendecinin Elde Bulundurma Maliyeti \\
& Üreticinin Stoku & Üreticinin Toplam Sipariş Verme Maliyeti \\
& Perakendecinin Stoku & Perakendecinin Toplam Sipariş Verme Maliyeti \\
& Üreticinin Stok Pozisyonu & Üreticinin Sipariş Verme Maliyeti \\
& Perakendecinin Stok Pozisyonu & Perakendecinin Sipariş Verme Maliyeti \\
& Üreticinin Yok Satma Maliyeti & Üreticinin Bozulan Ürün Maliyeti \\
& Perakendeci Yok Satma Maliyeti & Perakendecinin Bozulan Ürün Maliyeti \\
& Üretici Toplam Yok Satma Maliyeti & Üreticinin Toplam Bozulan Ürün Maliyeti \\
& Perakendeci Toplam Yok Satma Maliyeti & Perakendecinin Toplam Bozulan Ürün Maliyeti \\
& Üretici Toplam Elde Bulundurma Maliyeti & Üreticinin Stoklarının Toplam Kalan Yaşı \\
& Perakendecinin Stoklarının Toplam Kalan Yaşı \\
& Ürünün Üreticiye Ulaşma Zamanı Perakendeciye Ulaşma Zamanı \\
& & Perakendeci Toplam Elde Bulundurma Maliyeti \\
\hline
\end{tabular}

Çalışmada kullanılan yöntemlerin akışı Şekil 2'de gösterilmiştir. Çalışmada öncelikle problem ve amaç belirlenerek modellenmesi gerçekleştirilmiştir. Model üzerinde çoklu senaryolar oluşturularak, bu senaryolar simülasyon yoluyla çalıştırılmış ve karşılaştırmaları gerçekleştirilerek hangi parametrelerin daha duyarlı olduğu gözlemlenmeye çalışılmıştır. Ayrıca tedarik zinciri oyuncuları arasında bilgi paylaşımı durumu incelenmiş ve tedarik zincirinin farklı karar vericiler tarafından yönetildiği merkezi olmayan (decentralized) tedarik zinciri ile tüm tedarik zincirinde verilen kararların tek bir yapıdan çıktığı merkezi (centralized) tedarik zincirinin performans karşılaştırılması gerçekleştirilmiştir. 


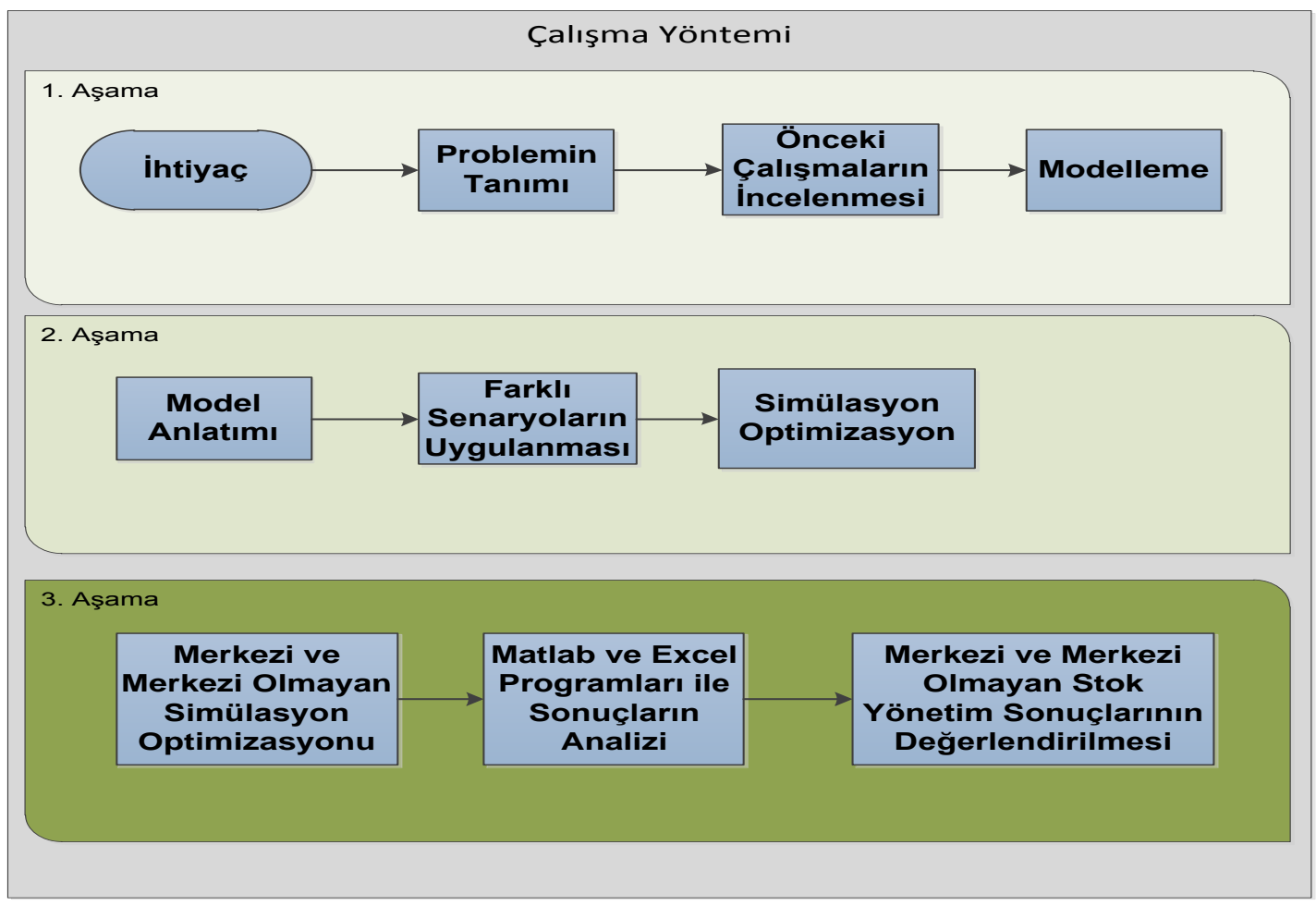

Şekil 2. Çalışmada kullanılan yöntem

Modeldeki varsayımlar şu şekilde özetlenebilir:

- Tedarik zinciri yapısı üretici, perakendeci ve müşteriden oluşan çok aşamadan oluşmaktadır.

- Ürünlerin kısa ömürlü olduğu varsayılmıştır.

- Ömrü dolan ürünler sistemden çekilmekte ve bozulma maliyetine sebep olmaktadır. Ayrıca perakendeciye ulaştığında bozulacak ürünler, üretici tarafından perakendeciye gönderilmemektedir.

- Talep belirsiz, müşteri gelişleri gün içerisinde rassaldır.

- Üretici, sonsuz kaynağa sahip bir tedarikçiden siparişlerini karşılamaktadır.

- Karşılanmayan müşteri talebi daha sonraki dönemlerde karşılanmamakta ve kaybolmaktadır. Karşılanamayan perakendeci siparişleri daha sonraki dönemlerde karşılanmak üzere beklemektedir (gecikmiş sevkiyat).

- Ürünler sistemden ilk giren ilk çıkar (FIFO) çekme prensibine göre çekilmektedir.

- Temin süresi sabit olup üretici ve perakendeci için aynı süreler alınmıştır.

- Perakendeci ve üretici için elde bulundurma, sipariş verme, yok satma ve bozulma maliyetleri bulunmaktadir.

Perakendecinin stok kontrolü, talebin karşılanması ve ürünlerin yaş bilgilerinin kontrolü ve yaşlandırılması modüllerinin ekran görüntüleri Şekil 3' de gösterilmiştir. Müşteri talebinden hemen sonra perakendeci ilk olarak stok kontrolünü miktara göre yapmaktadır. Yeterli stok bulunmaması durumunda müşteri talebi karşılanamamakta, stok pozisyonu kontrol edilerek üreticiye sipariş verilmektedir. Yeterli stok bulunması durumunda ise müşteri talebi karşılanmakta, stok pozisyonunu güncellemektedir. Stok pozisyonundan sonra diğer bir stok kontrol noktası ise, stoktaki ürünlerin yaş sorgusunun yapılmasıdır. 
Stoktaki ürünlerin kalan yaşları yeterli olmaması durumunda tekrar üreticiye sipariş verilmekte ve stok pozisyonu güncellenmektedir. Üreticinin akış diyagramı da benzer şekilde gerçekleşmektedir.

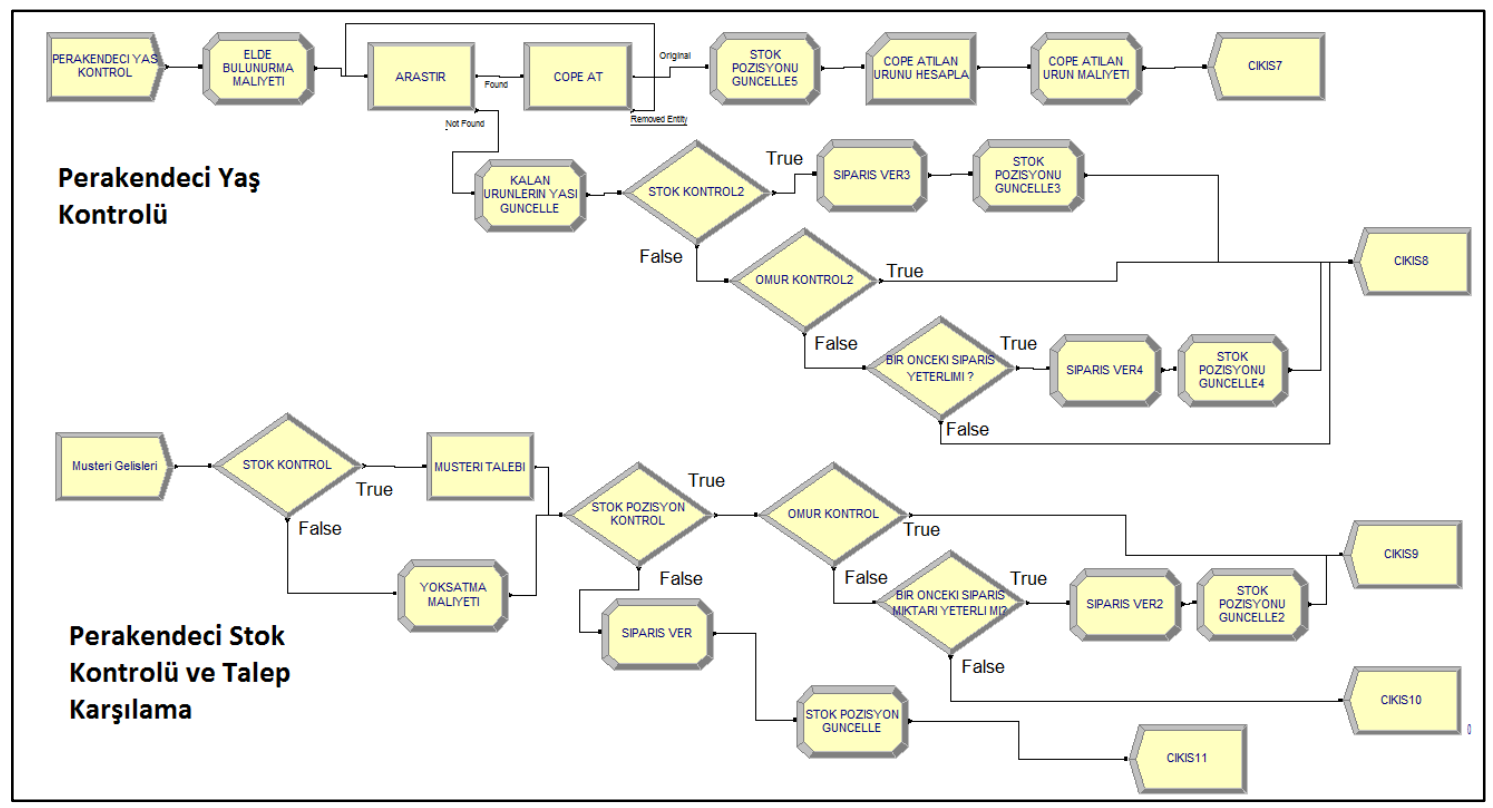

Şekil 3. Müşteri Talebinin Karşılanması ve Perakendeci Stok-Yaş Kontrolü Süreçleri

\section{Deneysel çalışmalar}

Tedarik zinciri yapısı içerisinde kısa ömürlü ürünlerin stok yönetimi için geliştirilen model 240 (10 gün) saati ısınma periyodu olmak üzere toplam 43850 saat (beş yıl) süresi boyunca simüle edilmiş ve toplam maliyeti minimum veren sonuçlara göre optimize edilmesi hedeflenmiştir. Üreticinin ve perakendecinin $(S, s)$ politikasına göre sipariş noktaları, stokta bulunan ürünlerin kalan yaşı için alt sınır ve yaş kontrolü sonucunda perakendecinin üreticiye verdiği sipariş miktarı $(Q)$ karar değişkenlerini oluşturmaktadır.

Model farklı ürün yaşı, müşterilerin talep miktarı, ürünün temin süresi, yok satma ve ürünün bozulma maliyeti için çalıştırılmış ve karşılaştırılmıştır. Toplam maliyetin minimize edilmesi ve müşteri memnuniyet düzeyinin arttırılması farklı senaryolarda incelenmiştir. Ürünün yaşı 4, 6 ve 8 gün gibi çok kısa olduğu durumlar ve müşteri talebinin fazla (Üstel; 0,01) ve düşük olduğu (Üstel; 0,05) durumlar dikkate alınmıştır.

Tablo 2. Faktörler ve düzeyleri

\begin{tabular}{ll}
\hline Faktör & Düzeyi \\
Yaş & $4-6-8$ (gün) \\
Talepler arası süre & Üstel $(0,01)$ - Üstel $(0,05)$ \\
Temin süresi & $1-2$ (gün) \\
Yok satma maliyeti & $2-5$ (birim) \\
Bozulma maliyeti & $2-5$ (birim) \\
\hline
\end{tabular}

Tablo 2'de gösterilen parametre değerlerinden 40 farklı senaryo incelenmiştir. Parametre değerlerinden temin süresi 2 (gün) alındığında, hem üreticide hem de perakendecide ayrı ayrı iki gün 
geçireceğinden pratik olmayan ürünün yaşı 4 (gün) olan kombinasyonlar incelenen senaryolardan çıkarılmıştır.

\section{Sonuçlar}

Modelde üreticinin ve perakendecinin dört maliyet parametresinden sipariş verme, elde bulundurma, yok satma ve bozulan ürün maliyeti toplam maliyeti oluşturmaktadır. Toplam maliyet minimize edilmesi aşamasında özellikle yok satma maliyeti minimize edilerek müşteri memnuniyet düzeyinin arttırılması hedeflenmektedir. Tablo 3'de 40 senaryonun ortalama toplam maliyet, tedarikçi maliyeti, perakendeci maliyeti ve müssteri hizmet düzeyi farklı parametre seviyeleri için değerleri gösterilmiştir.

Şekil 4a'da sonuçları gösterilen toplam maliyet değerleri incelendiğinde, ürünün yaşının toplam maliyete etkisi beklenildiği gibi hızlı bozulan ürünler toplam maliyeti arttırmaktadır. Başka deyişle ürünün yaşı azaldıkça toplam maliyet artmaktadır. Ayrıca, talep miktarı ile maliyet doğru orantılı şekilde artmaktadır. Bunda yüksek talep değerlerinden dolayı daha yüksek stok seviyelerinin tutulması ve sipariş maliyetinin daha yüksek olması önemli rol oynamaktadır. Yok satma maliyetinin 2 ve 5 birim olduğu farklı düzeyler incelenmiştir. Genel olarak yok satma maliyeti arttığında toplam maliyet artmaktadır. Model bozulma maliyeti yüksek olduğu durumda stokta daha az ürün bulundurmuş ve toplam maliyete etkisini azaltmıştır. Ortalama maliyete etkisi her iki durumda yaklaşık değerler çıkmıştır. Son olarak, temin süresi geciktikçe maliyetin arttığı gözlemlenmiştir.

Tablo 3. Farklı parametre sevileri için kıyas tablosu

\begin{tabular}{|c|c|c|c|c|c|}
\hline Parametre & Seviye & $\begin{array}{c}\text { Tedarikçi } \\
\text { Maliyeti (x1000) }\end{array}$ & $\begin{array}{c}\text { Perakendeci } \\
\text { Maliyeti (x1000) }\end{array}$ & $\begin{array}{l}\text { Toplam Maliyet } \\
\text { (x1000) }\end{array}$ & $\begin{array}{l}\text { Müşteri Hizmet } \\
\text { Düzeyi (\%) }\end{array}$ \\
\hline \multirow{3}{*}{ Ürün Raf Ömrü } & 4 & 16,53 & 34,65 & 51,18 & 94,29 \\
\hline & 6 & 13,14 & 25,42 & 38,56 & 95,87 \\
\hline & 8 & 11,30 & 15,90 & 26,74 & 98,93 \\
\hline \multirow{2}{*}{ Talep Değiş̧kenliği } & Üstel $(0,01)-1$ & 18,75 & 30,01 & 48,40 & 98,94 \\
\hline & Üstel $(0,05)-2$ & 7,41 & 16,90 & 24,31 & 94,62 \\
\hline \multirow{2}{*}{ Temin Süresi } & 1 & 11,45 & 20,65 & 31,79 & 97,65 \\
\hline & 2 & 15,53 & 27,68 & 43,21 & 95,47 \\
\hline \multirow{2}{*}{ Yok Satma Maliyeti } & 2 & 11,18 & 18,60 & 29,77 & 96,19 \\
\hline & 5 & 14,99 & 28,32 & 42,94 & 97,36 \\
\hline \multirow{2}{*}{ Bozulma Maliyeti } & 2 & 13,75 & 21,69 & 35,07 & 97,53 \\
\hline & 5 & 12,41 & 25,23 & 37,64 & 96,02 \\
\hline \multicolumn{2}{|c|}{ Ortalama } & 13,08 & 23,46 & 36,36 & 96,78 \\
\hline
\end{tabular}

Tedarik zinciri yapısında maliyet oranlarının yanında müşteri memnuniyeti etkisi de incelenmiştir. Müşteri memnuniyetinin sağlanabilmesi, müşteri talebinin zamanında karşılanabilmesi ile mümkündür. Karşılanan müşteri talebinin, toplam talep miktarına bölünerek hesaplanan müşteri talebini karşılama oranı veya müşteri memnuniyet seviyesi Şekil $4 b$ 'de analiz edilmiştir. Müşteri talebini karşılama oranının beş faktör ve seviyeleri içinde \%95 üzeri olduğu görülmektedir. Ürün yaşı arttıkça bozulan ürün sayısı azalmakta ve talep karşılama oranı artarak \%100 seviyelerine yaklaşmaktadır. 


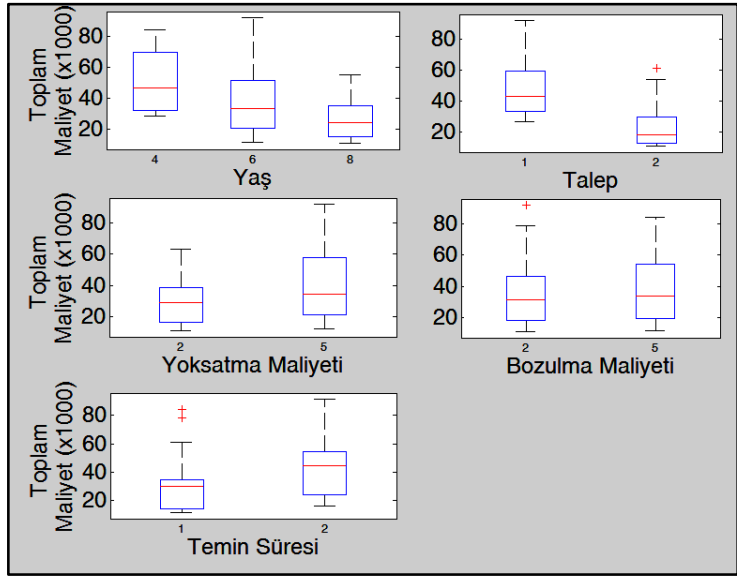

Şekil 4a. Toplam maliyete göre sonuçlar

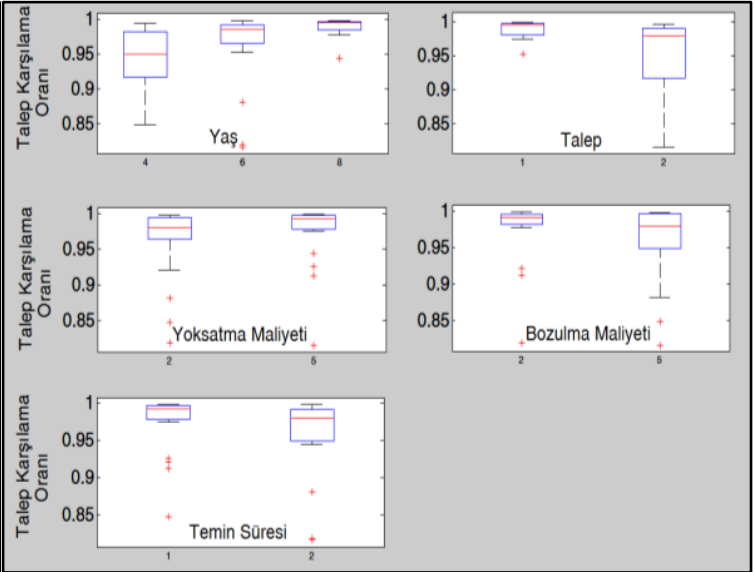

Şekil 4b. Talep karşıllama oranları

\section{Merkezi ve merkezi olmayan tedarik zinciri yönetimi}

40 farklı senaryonun bulgularında şimdiye kadar merkezi tedarik zincirinin yönetimi incelenmiş ve sonuçları gösterilmiştir. Farklı bir yaklaşım tarzı ile perakendeci ve üreticinin sadece kendi stok politikalarını yönettiği yani kendi maliyetlerinin minimize etmeye çalıştıkları durumlar incelenmiştir.

Tablo 4'de verilen üç farklı senaryo ele alınmış, ürünün üç farklı (4,6 ve 8) yaş ve üç farklı talep (fazla, orta ve az) miktarları incelenmiştir. Her bir senaryo için merkezi ve merkezi olmayan toplam maliyet değerleri hesaplanarak karşılaştırılmıştır.

Tablo 4. Merkezi ve merkezi olmayan tedarik zinciri yönetimi için senaryo değerleri

\begin{tabular}{llllllll}
\hline Senaryo & Yaş & Talep & $\begin{array}{l}\text { Elde } \\
\text { bulundurma } \\
\text { maliyeti }\end{array}$ & $\begin{array}{l}\text { Yok satma } \\
\text { maliyeti }\end{array}$ & $\begin{array}{l}\text { Sipariş } \\
\text { verme } \\
\text { maliyeti }\end{array}$ & $\begin{array}{l}\text { Bozulma } \\
\text { maliyeti }\end{array}$ & $\begin{array}{l}\text { Temin } \\
\text { süresi }\end{array}$ \\
1 & 4 & Üstel $(0,01)$ & 0,1 & 2 & 2 & 2 & 1 \\
2 & 6 & Üstel $(0,05)$ & 0,1 & 2 & 2 & 2 & 1 \\
3 & 8 & Üstel $(0,2)$ & 0,1 & 2 & 2 & 2 & 1 \\
\hline
\end{tabular}

Perakendecinin ve üreticinin toplam maliyet değerleri, merkezi ve merkezi olmayan stok yönetimi üç senaryo içinde Şekil 5'de incelenmiştir. Merkezi olmayan stok yönetiminde, perakendeci ve üretici öncelikle kendi maliyet değerlerini minimize etmeye çalışmaktadır. Perakendeci maliyetini minimize edecek stok yönetimi uyguladığında, üretici maliyetinin çok yüksek çıktığı gözlemlenmiştir. Benzer durum üretici kendi maliyetini azalttığında, perakendeci maliyetinin çok yüksek çıktığ1 ölçülmüş̧ür. Bundan dolayı merkezi stok yönetimi uygulanmadığında, tedarik yapısında bulunan aşamalardan bazılarının maliyet değeri optimize edilebilmesine karşılık tedarik yapısının toplam maliyeti, merkezi stok yönetiminin toplam maliyetine göre çok daha yüksek olduğu ölçülmüştür. 


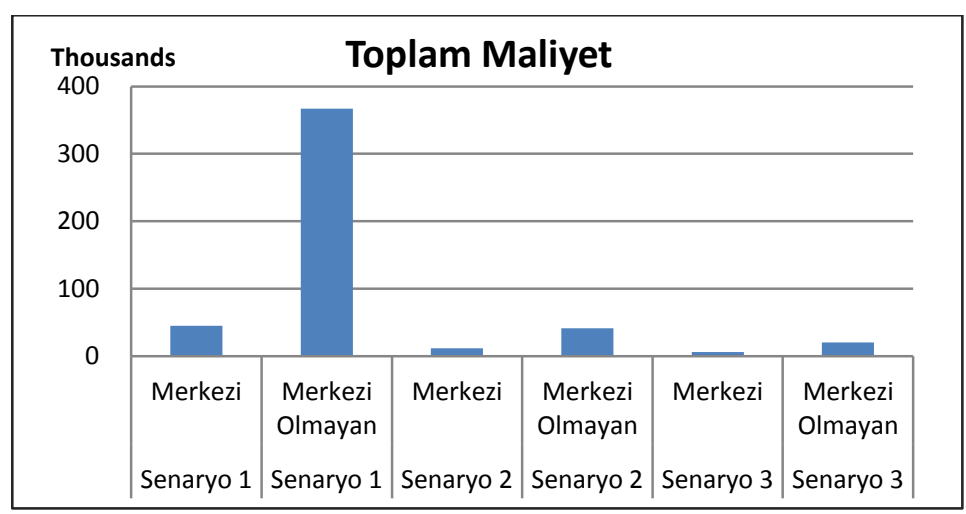

Şekil 3. Senaryo 1, 2 ve 3 için merkezi ve merkezi olmayan toplam maliyet değerleri

\section{Bilgi paylaşımı}

Merkezi stok yönetimi çalışmasında müşteri talebi, perakendeci ve üretici siparişlerinin dağılımı incelenmiştir. Perakendecinin ve üreticinin maliyetlerini bütün olarak minimize edebilmek için bilgi paylaşımına ihtiyaç duyulmaktadır. Özellikle kısa ömürlü ürünlerin hızlı bir şekilde müşteriye ulaştırılması gerektiği düşünüldüğünde bilgi paylaşımının önemi çok daha fazla artmaktadır.

Merkezi tedarik zinciri yönetimi sonucunda Tablo 4'da yer alan senaryo 2 için bilgi paylaşımı etkisinin grafiği Şekil 6'da gösterilmiştir. Müşteri talebinin, perakendecinin ve üreticinin siparişi birbiri içerisinde orantılı şekilde olduğu görülmektedir. Perakendeci ve üretici fazla sipariş vermekten kurtulmuş, bu sayede elde bulundurma ve bozulma maliyetleri minimize edilmiştir.

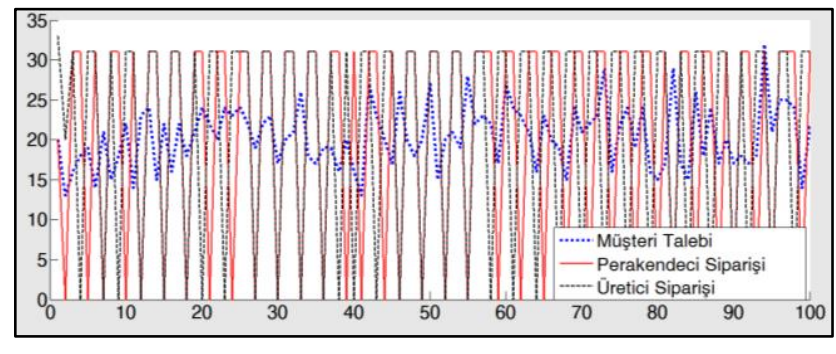

Şekil 6. Senaryo 2 için bilgi paylaşımının etkisi

\section{Değerlendirme ve sonuçlar}

Kısa ömürlü ürünlerin stok yönetimi yeni bir stok politikası geliştirilerek modellenmiş ve simüle edilmiştir. Müşteri, perakendeci ve üreticiden oluşan çok aşamalı model yapısı, merkezi ve merkezi olmayan stok yönetim yaklaşımları incelenmiştir. Toplam tedarik zinciri maliyetinin (sipariş maliyeti, yok satma maliyeti, elde bulundurma maliyeti, bozulan ürün maliyeti) minimize edilmesi ve müşteri memnuniyet seviyesinin arttırılması geliştirilen stok politikaları ile sağlanmış ve sonuçlar benzetim yoluyla gösterilmiştir.

$\mathrm{Bu}$ çalışmada, klasik stok yönetiminde sipariş noktalarını belirlemek için miktar kontrolünün yanında, stokta bulunun ürünlerin kalan yaşları dikkate alınmıştır. Bu sayede stoksuz kalma, yok satma ve bozulan ürün maliyetlerinin azaltılması sağlamıştır. Çalışmada kullanılan parametrelerden, ürünün yaşı, talep miktarı, temin süresi, bozulma maliyeti ve yok satma maliyeti değerleri değiştirilerek 40 farklı senaryo simüle edilerek üreticinin ve perakendecinin maliyetlerine bu faktörlerin etkisi incelenmiştir. 
Çalışmada uygulanan 40 farklı senaryoda toplam maliyeti en az hesaplanan senaryoların karar değişkenleri analiz edildiğinde; model parametre değerlerinden bir tanesinin değişmesi durumunda bile sipariş verme noktaları ile ürünlerin kalan ömrü için gerekli olan alt sınır değerlerinde önemli farklılıkların olduğu gözlemlenmiştir. Toplam maliyeti en az hesaplanan senaryoların ortak özelliği, talebin orta ve ürünün yaşının diğer senaryolara kıyasla daha uzun ömürlü olmasıdır. Bu durum bize ürünün ömrünün '2 gün’’ bile uzamasının maliyete önemli etkisinin olduğunu göstermiştir.

Tedarik ağının merkezi stok yönetim tarzı, merkezi olmayan stok yönetime göre çok daha kârlı ve uygulanabilir olduğu gözlemlenmiştir. Merkezi olmayan stok yönetiminde, her oyuncu kendi stok politikasını belirlediğinde bozulan ürün miktarı artarak çok daha fazla ürünün atılmasına neden olmakta ve toplam maliyetin arttığı gözlemlenmiştir.

Gerçek hayatta tedarik ağında tedarikçi, dağıtıcı, toptancı, gibi model yapısından çok daha fazla aşamanın olduğu bilinmektedir. Bundan sonraki çalışmalarda, tedarik zinciri yapısında üçten daha fazla aşamanın olduğu stok yönetim modelleri incelenebilir. Ayrıca müşterilerin, kısa ömürlü ürünlerde her zaman taze ürünü talep edeceği gerçeği göz önüne alınarak ürünlerin sistemden son giren ilk çıkar (LIFO) prensibine göre çekilmesi dikkate alınarak stok yönetimi modelleme çalışmaları yapılabilir.

\section{Kaynaklar}

[1] Kaneti H., Gelişmiş Ülkelerde gerçekleşen gıda israfının açlık ve yoksulluğa etkisi. “http://www.mbmtr.org/uploads/1/7/9/4/17943871/gk7_1_harunkaneti.pdf”, 2014. (Erişim tarihi: Aralık 2016).

[2] Tekin E., Gürler Ü., Berk E., "Age-based vs. stock level control policies for a perishable inventory system.” European Journal of Operational Research, 2001, 134.2: 309-329.

[3] Görener Ali., "Tedarik Zinciri Stratejisi Seçimi: Bulanık VIKOR Yöntemiyle İmalat Sektöründe Bir Uygulama.", Uluslararası Alanya İşletme Fakültesi Dergisi 5.3, 2013.

[4] Pierskalla W. P., Roach C. D., "Optimal issuing policies for perishable inventory." Management Science, 1972, 18.11: 603-614.

[5] Katsaliaki K., "Cost-effective practices in the blood service sector." Health Policy, 2008, 86.2: 276-287.

[6] Rytilä J. S., Spens K. M., "Using simulation to increase efficiency in blood supply chains." Management Research News, 2006, 29.12: 801-819.

[7] Kärkkäinen Mikko., "Increasing efficiency in the supply chain for short shelf life goods using RFID tagging.” International Journal of Retail \& Distribution Management, 2003, 31.10: 529536.

[8] Van Z., Gideon J. J., "Inventory control for perishable commodities." North Carolina State University, 1964.

[9] Nahmias S., "Optimal ordering policies for perishable inventory-II." Operations Research, 1975, 23.4: 735-749. 
[10] Fries B. E., "Optimal ordering policy for a perishable commodity with fixed lifetime." Operations Research, 1975, 23.1: 46-61.

[11] Nahmias S., "Perishable inventory theory: A review." Operations Research, 1982, 30.4: 680708 .

[12] Goyal S. K., Giri B. C., "Recent trends in modeling of deteriorating inventory." European Journal of Operational Research, 2001, 134.1: 1-16.

[13] Karaesmen I. Z., Scheller-Wolf A., Deniz B., "Managing perishable and aging inventories: review and future research directions." In: Planning production and inventories in the extended enterprise. Springer US, 2011. p. 393-436.

[14] Bakker M., Riezebos J., Teunter R. H., "Review of inventory systems with deterioration since 2001.” European Journal of Operational Research, 2012, 221.2: 275-284.

[15] Padmanabhan G., Vrat P., "EOQ models for perishable items under stock dependent selling rate.” European Journal of Operational Research, 1995, 86.2: 281-292.

[16] Kalpakam S., Shanthi S., "A perishable system with modified base stock policy and random supply quantity." Computers \& Mathematics with Applications, 2000, 39.12: 79-89.

[17] Broekmeulen R. A., Van D., Karel H., "A heuristic to manage perishable inventory with batch ordering, positive lead-times, and time-varying demand." Computers \& Operations Research, 2009, 36.11: 3013-3018.

[18] Ghandforoush P., Sen T. K., “A DSS to manage platelet production supply chain for regional blood centers.” Decision Support Systems, 2010, 50.1: 32-42.

[19] Chatfield D. C., Kim J. G., Harrison T. P., Hayya J. C., "The bullwhip effect—impact of stochastic lead time, information quality, and information sharing: a simulation study." Production and Operations Management, 2004, 13.4: 340-353.

[20] Disney S. M., Towill D. R., "The effect of vendor managed inventory (VMI) dynamics on the Bullwhip Effect in supply chains.” International Journal of Production Economics, 2003, 85.2: 199-215.

[21] Lee H. L., Padmanabhan V., Whang, S., "The bullwhip effect in supply chains." Sloan Management Review, 1997, 38.3: 93.

[22] Wu Y. N., Cheng T. E., "The impact of information sharing in a multiple-echelon supply chain." International Journal of Production Economics, 2008, 115.1: 1-11.

[23] Sarathi G. P., Sarmah S. P., Jenamani M., "An integrated revenue sharing and quantity discounts contract for coordinating a supply chain dealing with short life-cycle products.” Applied Mathematical Modelling, 2014, 38.15: 4120-4136.

[24] Merkuryev Y. A., Petuhova J. J., Van Landeghem R., Vansteenkiste S., "Simulation-based analysis of the bullwhip effect under different information sharing strategies." In: Proceedings 14th European Simulation Symposium. Germany, Dresden, 2002.

[25] Vieira G. E., "Ideas for modeling and simulation of supply chains with Arena." In Simulation Conference, 2004. Proceedings of the 2004 Winter. pp. 1418-1427. 
[26] Kouki, C., Jouini, O. , "On the effect of lifetime variability on the performance of inventory systems.” International Journal of Production Economics, 2015, 167, 23-34.

[27] Luo, K., Bollapragada, R., Kerbache, L., "Inventory allocation models for a two-stage, twoproduct, capacitated supplier and retailer problem with random demand." International Journal of Production Economics, 2017, 187, 168-181.

[28] Kaasgari, M. A., Imani, D. M., \& Mahmoodjanloo, M., “Optimizing a vendor managed inventory (VMI) supply chain for perishable products by considering discount: Two calibrated meta-heuristic algorithms." Computers \& Industrial Engineering, 2017, 103, 227-241.

[29] Taleizadeh, A. A., Noori-daryan, M., \& Cardenas-Barron, L. E., "Joint optimization of price, replenishment frequency, replenishment cycle and production rate in vendor managed inventory system with deteriorating items." International Journal of Production Economics, 2015, 159, 285-295.

[30] Önal, M., Romeijn, H. E., Sapra, A., \& van den Heuvel, W., “The economic lot-sizing problem with perishable items and consumption order preference." European Journal of Operational Research, 2015, 244(3), 881-891.

[31] Pauls-Worm, K. G., Hendrix, E. M., Alcoba, A. G., Haijema, R., “Order quantities for perishable inventory control with non-stationary demand and a fill rate constraint." International Journal of Production Economics, 2016, 181, 238-246. 